\title{
Demonstration of Balamuthia and Acanthamoeba mitochondrial DNA in sectioned archival brain and other tissues by the polymerase chain reaction
}

Shigeo Yagi • Frederick L. Schuster •

Govinda S. Visvesvara

Published online: 15 March 2008

(C) Springer-Verlag 2008

Erratum to: Parasitol Res (2008) 102:491-497

DOI 10.1007/s00436-007-0789-z

Due to a technical error, this article was unfortunately published twice.

The original (first) version of this article was published in Parasitol Res (2008) 102:211-217, and is available online at http://dx.doi.org/10.1007/s00436-007-0749-7.

The online version of the original article can be found at http://dx.doi. org/10.1007/s00436-007-0789-z.

S. Yagi $\cdot$ F. L. Schuster $(\bowtie)$

Viral and Rickettsial Disease Laboratory,

California Department of Public Health,

850 Marina Bay Parkway,

Richmond, CA 94804, USA

e-mail: Fred.Schuster@cdph.ca.gov

G. S. Visvesvara

Centers for Disease Control and Prevention,

Division of Parasitic Diseases,

Atlanta, GA 30341, USA 